\title{
Prevalence and characterization of extended-spectrum beta-lactamase-producing Enterobacteriaceae isolated in Canadian hospitals: Results from CANWARD 2007
}

\author{
Patricia J Baudry BSc ${ }^{1,2}$, Melissa McCracken MSc ${ }^{3}$, Philippe Lagacé-Wiens MD², Michael R Mulvey PhD ${ }^{1,3}$, \\ George G Zhanel $\mathrm{PhD}^{1,2}$, Daryl J Hoban $\mathrm{PhD}^{1,2}$
}

\begin{abstract}
PJ Baudry, M McCracken, P Lagacé-Wiens, MR Mulvey, GG Zhanel, DJ Hoban. Prevalence and characterization of extended-spectrum beta-lactamase-producing Enterobacteriaceae isolated in Canadian hospitals: Results from CANWARD 2007. Can J Infect Dis Med Microbiol 2009;20(Suppl A):43A-48A.
\end{abstract}

OBJECTIVE: The purpose of the present study was to determine the prevalence and molecular epidemiology of extended-spectrum beta-lactamase (ESBL)-producing Enterobacteriaceae identified from Canadian hospitals in 2007.

METHODS: Clinically significant isolates were collected as part of the Canadian Ward Surveillance Study (CANWARD 2007) from January to December 2007, inclusive, from 12 sentinel hospital centres across Canada. Minimum inhibitory concentrations were determined by broth microdilution, and putative ESBL isolates were confirmed by the Clinical and Laboratory Standards Institute disk diffusion method. Polymerase chain reaction and DNA sequencing were used to detect $b l a_{\mathrm{SHV}}, b l a_{\text {TEM }}, b l a_{\mathrm{CTX}-\mathrm{M}}$ and $b l a_{\text {OXA-like }}$ genes. Strains were typed using pulsed-field gel electrophoresis.

RESULTS: A total of $3.4 \%$ and $1.6 \%$ of Escherichia coli and Klebsiella pneumoniae, respectively, were identified as ESBL producers. Resistance to fluoroquinolones, doxycycline, trimethoprim/sulfamethoxazole and gentamicin occurred in $92.5 \%$ and $71.4 \%, 75.5 \%$ and $71.4 \%, 67.9 \%$ and $57.1 \%$, and $58.5 \%$ and $57.1 \%$ of ESBL-producing E coli and K pneumoniae, respectively. A total of $90.6 \%$ and $71.4 \%$ of ESBL-producing E coli and $\mathrm{K}$ pneumoniae were identified as multidrug resistant. The CTX-M type was the predominant ESBL, with CTX-M-15 as the predominant genotype. A total of $81.7 \%$ ESBL-producers carried several beta-lactamase genes. Pulsed-field gel electrophoresis revealed that the majority of ESBL producers were not genetically related (less than $80 \%$ homology). Similar patient demographics were observed among both ESBL-producing $E$ coli and $K$ pneumoniae.

CONCLUSION: CTX-M has become the most common enzyme among both ESBL-producing $E$ coli and $K$ pneumoniae. The spread of ESBLproducing bacteria across Canada is polyclonal and is not due to the clonal spread of a single strain.

Key Words: Canada; Characterization; Enterobacteriaceae; ESBL; Multidrug resistant; Prevalence

E xtended-spectrum beta-lactamases (ESBLs) are the most significant resistance determinants emerging and spreading worldwide among the Enterobacteriaceae (1). They were first reported in 1983 and since then, greater than 300 variants of ESBLs have been identified (http://www.lahey.org/Studies). The majority of ESBLs are Ambler Class A TEM, SHV and CTX-M variants. Until the late 1990s, TEM and SHV were the predominant ESBL variants and were mainly associated with nosocomial infections caused by Klebsiella pneumoniae $(2,3)$. The epidemiology of ESBLs has undergone a rapid

\section{Prévalence et caractérisation des}

entérobatériacées productrices de

bêtalactamases à spectre élargi isolées dans les hôpitaux canadiens : Résultats de l'étude CANWARD 2007

\begin{abstract}
OBJECTIF : Le but de la présente étude était de déterminer la prévalence et l'épidémiologie moléculaire des entérobactériacées productrices de bêtalactamase à spectre élargi (ou ESBL, pour extended-spectrum betalactamase) recensées dans les hôpitaux canadiens en 2007.

MÉTHODES : Des isolats cliniquement significatifs ont été recueillis dans le cadre de l'étude CANWARD (Canadian Ward Surveillance Study) 2007, entre janvier et décembre 2007, auprès de 12 centres hospitaliers sentinelles des quatre coins du Canada. Les concentrations minimales inhibitrices (CMI) ont été calculées par microdilution en bouillon de culture et les isolats d'ESBL potentiels ont été confirmés au moyen de la méthode de diffusion sur disque du Clinical and Laboratory Standards Institutes. Des tests de PCR (pour polymerase chain reaction) et de séquençage de l'ADN ont été utilisés pour détecter les gènes $b l a_{\mathrm{SHV}}, b l a_{\mathrm{TEM}}, b l a_{\mathrm{CTX}-\mathrm{M}}$ et $b l a_{\mathrm{type}} \mathrm{OXA}$. Les souches ont été typées par électrophorèse en champ pulsé.

RÉSULTATS : En tout, 3,4 \% et 1,6\% des isolats d'Escherichia coli et de Klebsiella pneumoniæ respectivement ont été associés à la fabrication d'ESBL. La résistance aux fluoroquinolones, à la doxycycline, au triméthoprime-sulfaméthoxazole et à la gentamicine a été observée chez $92,5 \%$ et $71,4 \%, 75,5 \%$ et $71,4 \%, 67,9 \%$ et $57,1 \%$ et $58,5 \%$ et $57,1 \%$ des isolats d'E coli et de K pneumoniæ producteurs d'ESBL, respectivement. En tout, 90,6 \% et 71,4\% des isolats d'E coli et de K pneumoniæ ont été jugés multirésistants. Le type CTX-M a été l'ESBL prédominant, avec le CTX-M-15 comme génotype A prédominant. En tout, 81,7 \% des isolats producteurs d'ESBL étaient porteurs de plusieurs gènes de la bêtalactamase. L'électrophorèse en champ pulsé a révélé que la majorité des souches productrices d'ESBL n'étaient pas génétiquement apparentées (moins de $80 \%$ d'homologie). Pour les isolats d'E coli et de K pneumoniæ producteurs d'ESBL, les caractéristiques des patients étaient similaires.

CONCLUSIONS : Le CTX-M est devenu l'enzyme la plus courante parmi les isolats d'E coli et $K$ pneumoniæ producteurs d'ESBL. La propagation des bactéries productrices d'ESBL au Canada est polyclonale et n'est pas attribuable à la propagation clonale d'une seule souche.
\end{abstract}

change over the past decade with the emergence and spread of CTX-M ESBLs. CTX-M ESBLs are now the most prevalent genotype and are mainly associated with Escherichia coli infections from both community and nosocomial infections $(2,4)$.

ESBLs are enzymes that compromise the efficacy of betalactam antibiotics, with the exception of the cephamycins and carbapenems, by hydrolysis of the beta-lactam ring $(3,5)$. Antimicrobial therapy is frequently limited for the treatment of ESBL producers because they are often multidrug resistant (MDR).

\footnotetext{
${ }^{1}$ Department of Medical Microbiology, Faculty of Medicine, University of Manitoba; ${ }^{2}$ Department of Clinical Microbiology, Health Sciences Centre;

${ }^{3}$ National Microbiology Laboratory, Public Health Agency of Canada, Winnipeg, Manitoba

Correspondence: Patricia J Baudry, Health Sciences Centre, Department of Clinical Microbiology, MS673-820 Sherbrook Street, Winnipeg, Manitoba,

R3A 1R9. Telephone 204-787-4684, fax 204-787-4699, e-mail trishbaudry@hotmail.com
} 


\begin{tabular}{|c|c|c|c|}
\hline Parameter & $\begin{array}{c}E \text { coli, } \\
\mathrm{n}=53\end{array}$ & $\begin{array}{c}K \text { pneumoniae, } \\
n=7\end{array}$ & $\mathbf{P}^{*}$ \\
\hline \multicolumn{4}{|l|}{$\overline{\text { Sex }}$} \\
\hline Male & $29(54.7)$ & $4(57.1)$ & NS \\
\hline Female & $24(45.3)$ & $3(42.9)$ & NS \\
\hline \multicolumn{4}{|l|}{ Age, years } \\
\hline$\leq 17$ & $0(0)$ & $1(14.3)$ & NS \\
\hline $18-65$ & $19(35.8)$ & $2(28.6)$ & NS \\
\hline$\geq 66$ & $34(64.2)$ & $4(57.1)$ & NS \\
\hline \multicolumn{4}{|l|}{ Patient region } \\
\hline British Columbia/Alberta $(n=2)^{\dagger}$ & $12(22.7)$ & $1(14.3)$ & NS \\
\hline Saskatchewan/Manitoba $(n=2)^{\dagger}$ & $5(9.4)$ & $1(14.3)$ & NS \\
\hline Ontario $(n=4)^{\dagger}$ & $29(54.7)$ & $3(42.9)$ & NS \\
\hline Quebec/Maritimes $(n=4)^{\dagger}$ & $7(13.2)$ & $2(28.6)$ & NS \\
\hline \multicolumn{4}{|l|}{ Patient type } \\
\hline Inpatient & $38(71.7)$ & $6(85.7)$ & NS \\
\hline Outpatient & $15(28.3)$ & $1(14.3)$ & NS \\
\hline \multicolumn{4}{|l|}{ Hospital ward } \\
\hline Outpatient clinic & $8(15.0)$ & $1(14.3)$ & NS \\
\hline Emergency room & $7(13.2)$ & $0(0)$ & NS \\
\hline Intensive care unit & $3(5.7)$ & $1(14.3)$ & NS \\
\hline Medical ward & $26(49.1)$ & $4(57.1)$ & NS \\
\hline Surgical ward & $9(17.0)$ & $1(14.3)$ & NS \\
\hline \multicolumn{4}{|l|}{ Specimen type } \\
\hline Urine & $15(28.3)$ & $1(14.3)$ & NS \\
\hline Blood & $34(64.2)$ & $4(57.1)$ & NS \\
\hline Wound & $1(1.9)$ & $1(14.3)$ & NS \\
\hline Respiratory tract & $3(5.7)$ & 1 (14.3) & NS \\
\hline
\end{tabular}

${ }^{*}$ Comparison of demographics, hospital wards and specimen types among ESBL-producing E coli and ESBL-producing K pneumoniae; ${ }^{\dagger}$ Number of hospitals per region. NS Not significant; $P>0.05$

The purpose of the present study was to determine the prevalence and molecular epidemiology of ESBL-producing Enterobacteriaceae isolated from Canadian hospitals in 2007.

\section{MATERIALS AND METHODS}

Bacterial strains from surveillance study

Bacterial isolates were collected as part of the Canadian Ward Surveillance Study (CANWARD 2007). CANWARD is a laboratory-based surveillance study coordinated by the Health Sciences Centre in Winnipeg, Manitoba. From January 1 through December 31, 2007, inclusive, 12 sentinel hospital centres across Canada submitted pathogens from patients attending hospital clinics, emergency rooms, medical and surgical wards, and intensive care units. Each centre was asked to submit pathogens (consecutive, one per patient/infection site) from blood $(n=360)$, respiratory $(n=200)$, urine $(n=100)$, and wound/intravenous $(n=50)$ infections. If the centres did not collect a minimum of 20 ESBL producers within these objectives, they were asked to continue to collect above the objectives until a minimum of 20 was fulfilled. All isolates were identified at participating sites by routine procedures performed at each laboratory. Isolates were shipped to the reference laboratory at the Winnipeg Health Sciences Centre on Amies charcoal swabs, subcultured onto blood agar, and stocked in skim milk at $-80^{\circ} \mathrm{C}$ until minimum inhibitory concentration (MIC) testing was carried out. In the present study, only the analysis of unique ESBLproducing Enterobacteriaceae isolates that fell within the CANWARD 2007 objectives will be reported.

\section{Antimicrobial susceptibility testing}

Following two subcultures from frozen stock, the in vitro activities of various antimicrobials were determined in triplicate by microbroth dilution in accordance with Clinical and Laboratory Standards Institute (CLSI) guidelines (6). Colistin (polymyxin E) MICs were determined using the E-test method. Food and Drug Administration (USA) interpretation breakpoints were used for tigecycline (susceptible: $2 \mu \mathrm{g} / \mathrm{mL}$ or less, intermediate: $4 \mu \mathrm{g} / \mathrm{mL}$ and resistant: $8 \mu \mathrm{g} / \mathrm{mL}$ or greater) and colistin (susceptible: $2 \mu \mathrm{g} / \mathrm{mL}$ or less and resistant: $4 \mu \mathrm{g} / \mathrm{mL}$ or greater). Strains concomitantly resistant to three or more different antimicrobial classes were defined as MDR.

Any E coli, K pneumoniae, Klebsiella oxytoca or Proteus mirabilis with a ceftriaxone MIC of $1 \mu \mathrm{g} / \mathrm{mL}$ or greater was identified as a putative ESBL and underwent further analysis. The putative ESBL phenotype was confirmed by the disk diffusion method as described by CLSI. E coli ATCC 25922 and K pneumoniae ATCC 700603 were the control strains used in the study.

\section{Characterization of ESBL genes}

Genotypic characterization of ESBLs was performed by polymerase chain reaction and sequencing of $b l a_{\mathrm{SHV}}, b l a_{\mathrm{TEM}}$, $b_{\text {CTX-M }}$ and bla OXA-like genes as previously described (7-9). A Basic Local Alignment Search Tool search of the DNA sequence was conducted to determine specific genotypes.

\section{Genetic relationships}

Genetic relationships of the ESBL-producing Enterobacteriaceae were assessed by pulsed-field gel electrophoresis following digestion with $\mathrm{XbaI}$ as previously described (7).

\section{Statistical analysis}

$\chi^{2}$ analysis was used to evaluate statistical significance, as appropriate, using Graphpad Quickcalcs (Graphpad Software Inc).

\section{RESULTS}

Epidemiology of ESBL-producing Enterobacteriaceae

A total of 7881 clinical isolates were collected as part of the CANWARD 2007 surveillance study. E coli, K pneumoniae, K oxytoca and $P$ mirabilis ranked first $(\mathrm{n}=1702,21.6 \%)$, fifth $(\mathrm{n}=457,5.8 \%), 11$ th $(\mathrm{n}=119,1.5 \%)$ and 14 th $(\mathrm{n}=100,1.3 \%)$, respectively, among all pathogens collected. Of those that fell within the CANWARD objectives, 93 of 1560 (6.0\%) E coli, 12 of 442 (2.7\%) K pneumoniae, seven of 119 (5.9\%) K oxytoca and three of 111 (2.7\%) P mirabilis had a ceftriaxone MIC of $1 \mu \mathrm{g} / \mathrm{mL}$ or greater and were identified as putative ESBL producers. Of those with a ceftriaxone MIC of $1 \mu \mathrm{g} / \mathrm{mL}$ or greater, 53 E coli and seven K pneumoniae were identified phenotypically as unique ESBL producers and were further analyzed. The prevalence of ESBL-producing E coli was 3.4\% (53 of 1560) and ranged from $1.1 \%$ in emergency rooms, $1.9 \%$ in intensive care units, $3.3 \%$ in hospital clinics, $6.2 \%$ in medical wards to 
TABLE 2

Comparison of antimicrobial susceptibilities of extended-spectrum beta-lactamase (ESBL)-producing and non-ESBLproducing isolates (Escherichia coli and Klebsiella pneumoniae)

\begin{tabular}{|c|c|c|c|c|c|c|c|c|c|c|c|c|c|}
\hline \multirow[b]{2}{*}{ Antibiotic } & \multicolumn{6}{|c|}{ ESBL-producing E coli $(n=53)$} & \multicolumn{6}{|c|}{ Non-ESBL-producing $E$ coli $\left(n=1507,{ }^{\dagger} n=504\right)$} & \multirow[b]{2}{*}{$P^{*}$} \\
\hline & $\mathrm{MIC}_{50}$ & $\mathrm{MIC}_{90}$ & Range & $\% \mathrm{~S}$ & $\%$ I & $\% \mathrm{R}$ & $\mathrm{MIC}_{50}$ & $\mathrm{MIC}_{90}$ & Range & $\% \mathrm{~S}$ & $\%$ I & $\% \mathbf{R}$ & \\
\hline$\overline{\mathrm{Amox} / \mathrm{Clav}^{\dagger}}$ & 8 & 16 & $2-32$ & 60.4 & 37.7 & 1.9 & 4 & 8 & $0.5-32$ & 93.2 & 5.6 & 1.2 & NS \\
\hline Cefazolin & 128 & $>128$ & $64->128$ & & & 100 & 2 & 8 & $\leq 0.5->128$ & 92.2 & 3.5 & 4.3 & 0.0001 \\
\hline Ceftriaxone & $>64$ & $>64$ & $2->64$ & 3.8 & 15.1 & 81.1 & $\leq 1$ & $\leq 1$ & $\leq 1->64$ & 98.2 & 1.0 & 0.8 & 0.0001 \\
\hline Cefepime & 16 & $>32$ & $\leq 1->32$ & 45.3 & 30.2 & 24.5 & $\leq 1$ & $\leq 1$ & $\leq 1->32$ & 99.6 & 0.3 & 0.1 & 0.0001 \\
\hline TZP & 4 & 16 & $\leq 1->512$ & 92.4 & 5.7 & 1.9 & $\leq 1$ & 4 & $\leq 1->512$ & 98.0 & 0.8 & 1.2 & NS \\
\hline Cefoxitin $^{\dagger}$ & 8 & 8 & $0.5->32$ & 92.4 & 5.7 & 1.9 & 4 & 8 & $\leq 0.06->32$ & 95.4 & 2.4 & 2.2 & NS \\
\hline Ertapenem $^{\dagger}$ & $\leq 0.06$ & 0.12 & $\leq 0.06-0.25$ & 100 & & & $\leq 0.06$ & $\leq 0.06$ & $\leq 0.06$ & 100 & & & NS \\
\hline Meropenem & $\leq 0.12$ & $\leq 0.12$ & $\leq 0.12$ & 100 & & & $\leq 0.12$ & $\leq 0.12$ & $\leq 0.12-0.5$ & 100 & & & NS \\
\hline Ciprofloxacin & $>16$ & $>16$ & $\leq 0.06->16$ & 7.5 & & 92.5 & $\leq 0.06$ & $>16$ & $\leq 0.06->16$ & 81.7 & 0.3 & 18.0 & 0.0001 \\
\hline Levofloxacin & 16 & 32 & $\leq 0.06->32$ & 7.5 & & 92.5 & $\leq 0.06$ & 16 & $\leq 0.06->32$ & 82.2 & 0.8 & 17.0 & 0.0001 \\
\hline Amikacin & 4 & 8 & $\leq 2->64$ & 94.3 & 3.8 & 1.9 & $\leq 2$ & 4 & $\leq 2->64$ & 99.9 & & 0.1 & NS \\
\hline Gentamicin & 32 & $>32$ & $\leq 0.5->32$ & 41.5 & & 58.5 & $\leq 0.5$ & 1 & $\leq 0.5->32$ & 93.1 & 0.5 & 6.4 & 0.0001 \\
\hline Doxycycline & 32 & $>256$ & $2->256$ & 22.6 & 1.9 & 75.5 & - & - & - & - & - & - & $\mathrm{N} / \mathrm{A}$ \\
\hline Tigecycline & 0.5 & 1 & $0.25-2$ & 100 & & & 0.25 & 0.5 & $0.06-4$ & 99.9 & 0.1 & & NS \\
\hline TMP/SMX & $>8$ & $>8$ & $\leq 0.12->8$ & 32.1 & & 67.9 & $\leq 0.12$ & $>8$ & $\leq 0.12->8$ & 77.2 & & 22.8 & 0.0001 \\
\hline Nitrofurantoin $^{\dagger}$ & 16 & 32 & $1-64$ & 96.2 & 3.8 & & 16 & 32 & $\leq 0.5-128$ & 96.6 & 2.6 & 0.8 & NS \\
\hline \multirow[t]{2}{*}{ Colistin $^{\dagger}$} & 1 & 1 & $\leq 0.06-4$ & 98.1 & & 1.9 & 0.5 & 1 & $\leq 0.06->16$ & 99.0 & & 1.0 & NS \\
\hline & \multicolumn{6}{|c|}{ ESBL-producing $K$ pneumoniae $(n=7)$} & \multicolumn{6}{|c|}{ Non-ESBL-producing $K$ pneumoniae $\left(n=435,{ }^{\dagger} n=185\right)$} & \\
\hline Antibiotic & $\mathrm{MIC}_{50}$ & $\mathrm{MIC}_{90}$ & Range & $\% \mathrm{~S}$ & $\%$ I & $\% \mathbf{R}$ & $\mathrm{MIC}_{50}$ & $\mathrm{MIC}_{90}$ & Range & $\% \mathrm{~S}$ & $\%$ I & $\% \mathbf{R}$ & $\mathbf{P}^{*}$ \\
\hline${\mathrm{Amox} / \mathrm{Clav}^{\dagger}}^{\dagger}$ & 8 & 16 & $8-16$ & 71.4 & 28.6 & & 2 & 4 & $1-16$ & 96.8 & 3.2 & & NS \\
\hline Cefazolin & 128 & $>128$ & $16->128$ & & 14.3 & 85.7 & 2 & 4 & $\leq 0.5->128$ & 96.1 & 1.4 & 2.5 & 0.0001 \\
\hline Ceftriaxone & $>64$ & $>64$ & $2->64$ & 28.6 & & 71.4 & 1 & 1 & $\leq 1-32$ & 99.8 & 0.2 & & 0.0001 \\
\hline Cefepime & 32 & 128 & $\leq 1-128$ & 42.9 & & 57.1 & 1 & 1 & $\leq 1->32$ & 99.8 & 0.2 & & 0.0001 \\
\hline TZP & 16 & $>512$ & $4->512$ & 57.1 & 14.3 & 28.6 & 2 & 8 & $\leq 1-512$ & 98.4 & 0.7 & 0.9 & 0.0031 \\
\hline Cefoxitin $^{\dagger}$ & 8 & $>256$ & $2->256$ & 71.4 & & 28.6 & 4 & 8 & $1->32$ & 93.0 & 4.3 & 2.7 & 0.0011 \\
\hline Ertapenem & $\leq 0.06$ & $\leq 0.06$ & $\leq 0.06-0.12$ & 100 & & & $\leq 0.06$ & $\leq 0.06$ & $\leq 0.06-0.25$ & 100 & & & NS \\
\hline Meropenem & $\leq 0.12$ & $\leq 0.12$ & $\leq 0.12$ & 100 & & & $\leq 0.12$ & $\leq 0.12$ & $\leq 0.12-0.25$ & 100 & & & NS \\
\hline Ciprofloxacin & $>16$ & $>16$ & $\leq 0.06->16$ & 28.6 & & 71.4 & $\leq 0.06$ & 0.5 & $\leq 0.06->16$ & 95.9 & 0.7 & 3.4 & 0.0001 \\
\hline Levofloxacin & 4 & $>16$ & $\leq 0.06->16$ & 28.6 & & 71.4 & $\leq 0.06$ & 0.5 & $\leq 0.06-32$ & 97.0 & 0.9 & 2.1 & 0.0001 \\
\hline Amikacin & 8 & $>64$ & $\leq 2->64$ & 85.7 & & 14.3 & $\leq 2$ & $\leq 2$ & $\leq 2-16$ & 100 & & & 0.0158 \\
\hline Gentamicin & 32 & $>32$ & $\leq 0.5->32$ & 42.9 & & 57.1 & $\leq 0.5$ & $\leq 0.5$ & $\leq 0.5->32$ & 99.0 & 0.5 & 0.5 & 0.0001 \\
\hline Doxycycline & 32 & 128 & $2-128$ & 14.3 & 14.3 & 71.4 & - & - & - & - & - & - & $\mathrm{N} / \mathrm{A}$ \\
\hline Tigecycline & 1 & 8 & $0.5-8$ & 85.7 & & 14.3 & 1 & 2 & $0.25-8$ & 95.2 & 3.7 & 1.1 & NS \\
\hline TMP/SMX & $>8$ & $>8$ & $\leq 0.12->8$ & 42.9 & & 57.1 & $\leq 0.12$ & 0.5 & $\leq 0.12->8$ & 94.7 & & 5.3 & 0.0003 \\
\hline Nitrofurantoin $^{\dagger}$ & 128 & 128 & $16-128$ & 14.3 & 14.3 & 71.4 & 64 & 128 & $8-256$ & 37.3 & 34.6 & 28.1 & 0.0252 \\
\hline Colistin $^{\dagger}$ & 0.5 & 0.5 & $0.5->16$ & 85.7 & & 14.3 & 0.5 & 1 & $0.12->16$ & 97.8 & & 2.2 & NS \\
\hline
\end{tabular}

${ }^{*}$ Comparison of resistant $(R)$ with nonresistant (susceptible [S] and intermediate [I]) isolates among ESBL-producing and non-ESBL-producing isolates. ${ }^{\dagger}$ Tested against fewer isolates of non-ESBL-producing isolates (E coli $n=504 ; K$ pneumoniae $n=185$ ). Amox/Clav Amoxicillin/clavulanate; Colistin (polymyxin $E$ ); $M I C_{50 / 90}$ Minimum inhibitory concentration (in $\mu \mathrm{g} / \mathrm{mL}$ ) required to inhibit the growth of 50\%/90\% of organisms; N/A Not available; NS Not significant, P>0.05; TMP/SMX Trimethoprim/sulfamethoxazole; TZP Piperacillin-tazobactam

$7.9 \%$ in surgical wards. ESBL-producing E coli was identified at 11 of the 12 sites and the prevalence ranged from $0 \%$ to $9.3 \%$ among participating hospitals. The prevalence of ESBLproducing $\mathrm{K}$ pneumoniae was $1.6 \%$ and ranged from $0 \%$ in emergency rooms, $1.3 \%$ in intensive care units, $2.1 \%$ in surgical wards, $2.2 \%$ in hospital clinics to $2.8 \%$ in medical wards. ESBL-producing $K$ pneumoniae was identified at five of the 12 sites with the prevalence ranging from $0 \%$ to $4.5 \%$ among participating hospitals. Patient demographics for ESBLproducing $E$ coli and $K$ pneumoniae are summarized in Table 1. The demographics for patients with ESBL-producing E coli and $K$ pneumoniae infections were similar $(\mathrm{P}>0.05$, not significant [NS]). The majority of patients were older than 66 years of age and were hospitalized in medical wards. No significant differences in the proportion of $E$ coli isolates identified as ESBL producers were obtained from blood (34 of $788 ; 4.4 \%$ ), respiratory tract (three of $100 ; 3.0 \%$ ) and wound (one of $37 ; 2.7 \%$ ) compared with urine ( 15 of $635 ; 2.4 \%)$ specimens ( $P>0.05$; NS). Similar observations were made for $\mathrm{K}$ pneumoniae, where no significant differences in the proportion of ESBL producers were obtained from wound (one of $17 ; 5.9 \%$ ), respiratory tract (one of $59 ; 1.7 \%$ ) and blood (four of $266 ; 1.5 \%$ ) compared with urine (one of $100 ; 1.0 \%$ ) specimens ( $\mathrm{P}>0.05$; NS).

Antimicrobial susceptibilities

Susceptibility testing demonstrated that resistance to fluoroquinolones, doxycycline, trimethoprim/sulfamethoxazole and gentamicin occurred in $92.5 \%$ and $71.4 \%, 75.5 \%$ and $71.4 \%$, $67.9 \%$ and $57.1 \%$, and $58.5 \%$ and $57.1 \%$ of ESBL-producing E coli and K pneumoniae, respectively (Table 2). Forty-eight of 


\begin{tabular}{|c|c|c|}
\hline Genotype* $^{*}$ & Organism & Number of isolates \\
\hline CTX-M-2, SHV-11 & K pneumoniae & 1 \\
\hline СТХ-M-3, TEM-1, OXA-1 & E coli & 1 \\
\hline СТX-M-14 & E coli & 3 \\
\hline CTX-M-14, TEM-1 & E coli & 14 \\
\hline СТХ-M-15 & E coli & 3 \\
\hline CTX-M-15, TEM-1 & E coli & 2 \\
\hline СТХ-M-15, OXA-1 & E coli & 16 \\
\hline СTX-M-15, SHV-1, OXA-1 & $K$ pneumoniae & 1 \\
\hline СTX-M-15, SHV-28, OXA-1 & $K$ pneumoniae & 1 \\
\hline СTX-M-15, TEM-1, OXA-1 & E coli & 8 \\
\hline $\begin{array}{l}\text { CTX-M-15, TEM-1, SHV-5, } \\
\text { OXA-1 }\end{array}$ & $K$ pneumoniae & 1 \\
\hline CTX-M-24, TEM-1 & E coli & 1 \\
\hline СТX-M-27 & E coli & 2 \\
\hline CTX-M-65 & E coli & 1 \\
\hline SHV2a & E coli & 1 \\
\hline Unknown, SHV-1 & K pneumoniae & 3 \\
\hline Unknown, TEM-1 & E coli & 1 \\
\hline
\end{tabular}

${ }^{*} T E M-1, S H V-1, S H V-11$ and OXA-1 are not ESBLS

$53(90.6 \%)$ and five of seven (71.4\%) ESBL-producing E coli and K pneumoniae were identified as MDR. All ESBL producers remained susceptible to the carbapenems. A comparison of antimicrobial susceptibilities between ESBL-producing and non-ESBL-producing isolates to various antimicrobials are summarized in Table 2. Not surprisingly, the ESBL producers displayed higher resistance rates to all antimicrobials tested with the exception of the carbapenems and tigecycline in comparison to non-ESBL producers.

\section{Distribution of beta-lactamase genes}

All isolates phenotypically identified as ESBL producers by the CLSI disk diffusion assay were subjected to PCR and sequencing to detect ESBL genes. All bla $a_{\mathrm{TEM}}, b l a_{\mathrm{SHV}}, b l a_{\mathrm{CTX}-\mathrm{M}}$ and bla $a_{\text {OXA-1,-2,-10 }}$ groups were detected in $49 \%, 1.9 \%, 96.2 \%$ and $47.2 \%$ of ESBL-producing E coli, respectively, and 14.3\%, $100 \%, 57.1 \%$ and $42.9 \%$ of ESBL-producing K pneumoniae, respectively (Table 3 ). Of the 53 ESBL-producing E coli, 51 (96.2\%) carried a CTX-M gene with 28 (52.8\%) bla CTX-M-15, 17 (32.1\%) bla $a_{\text {CTX-M-14 }}$, two (3.8\%) bla ${ }_{\text {CTX-M-27 }}$, and one (1.9\%) each of bla $a_{\text {СTX-M-3 }}, b l a_{\text {CTX-M-24 }}, b l a_{\text {CTX-M-65 }}, b l a_{\text {SHV2a }}$ and an unknown. Of the seven ESBL-producing K pneumoniae, three $(42.9 \%)$ carried bla CTX-M-15 $_{15}$, one (14.3) carried bla CTX-M-2 $_{1}$ and three were unknown. Forty-nine of 60 (81.7\%) ESBL producers carried several beta-lactamase genes (one to four betalactamase genes). $b l a_{\mathrm{TEM}-1}$ or a narrow-spectrum $b l a_{\mathrm{SHV}}$ gene were also carried among $26(49.1 \%)$ and zero of the ESBLproducing E coli and one (14.3\%) and five (71.4\%) of the ESBL-producing $K$ pneumoniae, respectively. The promoter regions of the $b l a_{\mathrm{TEM}-1}$ and $b l a_{\mathrm{SHV}-1}$ genes of the one E coli and three K pneumoniae with unidentified ESBL genes were investigated for mutations leading to hyperproduction causing the ESBL phenotype. However, no mutations in the promoter region were observed. Twenty-four of 28 (85.7\%) CTX-M-15 and the one CTX-M-3 ESBL-producing E coli as well as all

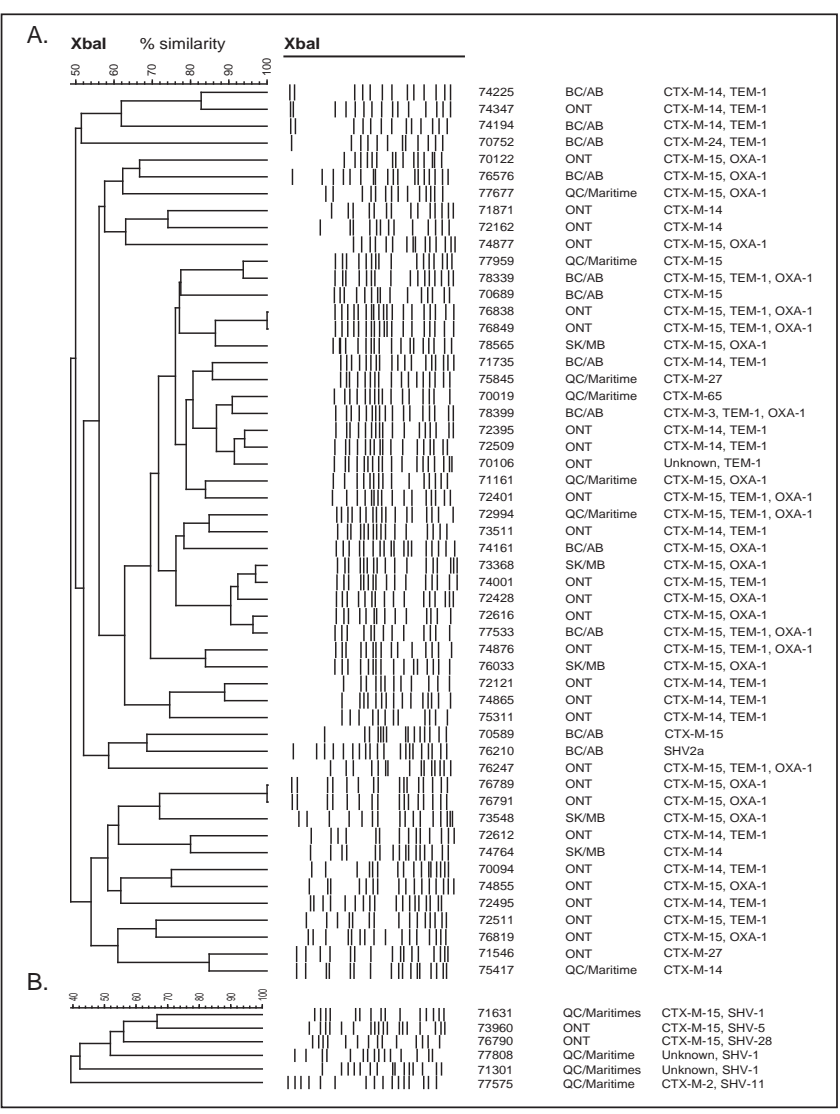

Figure 1) Pulsed-field gel electrophoresis dendrogram depicting the genetic relationships among extended-spectrum beta-lactamase (ESBL) producers. A ESBL-producing Escherichia coli; B ESBLproducing Klebsiella pneumoniae

three CTX-M-15-producing Kpneumoniae also carried bla $a_{\text {OXA-1 }}$. The distribution of beta-lactamase genes among ESBLproducing E coli and K pneumoniae are summarized in Table 3.

Genetic relationships among ESBL-producing E coli and K pneumoniae

Molecular typing using pulsed-field gel electrophoresis was conducted to study clonal relationships among ESBL-producing $E$ coli and $K$ pneumoniae. A dendrogram depicting the genetic relationships among ESBL-producing E coli and K pneumoniae isolates from Canadian hospitals is shown in Figure 1. The majority of ESBL-producing E coli were determined to be genetically unrelated (less than $80 \%$ homology). Several small clusters (two to five isolates) of genetically related ESBLproducing $E$ coli carrying the same type of CTX-M were observed. However, there were two clusters of two genetically related E coli from different regions of Canada with CTX-M genes from different CTX-M groups (CTX-M-1 and CTX-M-9 groups) suggesting two different acquisition events among the same strain.

Clonal spread was suggested to have occurred at one of the participating sites on two separate occasions involving two ESBL-producing E coli. The ESBL-producing $\mathrm{K}$ pneumoniae were determined to be genetically unrelated. A fingerprint was not obtained for one ESBL-producing $K$ pneumoniae due to autodigestion of the DNA. 


\section{DISCUSSION}

The prevalence and molecular epidemiology of ESBL-producing E coli and Klebsiella species in Canada has been monitored since the late 1990s (7-12). Throughout these studies, we have observed increases in the prevalence and changing trends in the molecular epidemiology of ESBL producers. The present study updates the prevalence and molecular epidemiology of ESBL producers among Canadian hospitals.

Our study found the prevalence of ESBL-producing E coli, K pneumoniae, Koxytoca and P mirabilis isolated from Canadian hospitals in 2007 to be 3.4\%, 1.6\%, 0\% and $0 \%$, respectively. These results are similar to the prevalence rates we observed from our Canadian Intensive Care Unit (CAN-ICU) Surveillance study from 2005 to 2006, where the prevalences of ESBL-producing E coli and Klebsiella species were determined to be $3.7 \%$ and $1.8 \%$, respectively $(9,12)$. However, in contrast to the CAN-ICU study, the majority of ESBL producers from the CANWARD 2007 study were obtained from medical wards (30 of 60 ESBL-producers; $50.0 \%$ ) with very few coming from intensive care units (four of 60 ESBL-producers; 6.7\%) $(\mathrm{P}=0.0001)$.

CTX-M ESBLs were the most common variants observed among both ESBL-producing $E$ coli and $K$ pneumoniae, with CTX-M-15 being the most common genotype among both as well as CTX-M-14 among E coli. This is not novel among ESBL-producing E coli $(9,10,12,13)$. However, this is the first report of CTX-M becoming the predominant enzyme among ESBL-producing $K$ pneumoniae in Canada, replacing SHV $(7,11)$. In addition, we describe the first CTX-M-65-producing E coli in Canada. CTX-M-65, a variant of CTX-M-14, was first reported and identified in the United States in 2008 (14).

The majority of ESBL-producing E coli also carried the narrowspectrum bla $a_{\mathrm{TEM}-1}$ gene, whereas ESBL-producing K pneumoniae more commonly carried a narrow-spectrum $b l a_{\mathrm{SHV}}$ gene.

E coli has become the predominant organism producing ESBLs in Canada over the past decade with the spread of CTX-M (9,12). However, with the emergence and increase of CTX-M-producing K pneumoniae, we may observe increases in their prevalence if CTX-M spreads as efficiently among $K$ pneumoniae as it did among $E$ coli.

Surprisingly, ESBL-producing $E$ coli and $K$ pneumoniae showed a trend to be more commonly isolated from blood, respiratory tract and wound specimens in comparison with urine specimens. This suggests that ESBL producers may be becoming more invasive; however, other factors that were not assessed by the present study could also be contributing to this observation, such as previous antimicrobial therapy, length of hospital stay and underlying disease.

\section{REFERENCES}

1. Ko KS, Lee MY, Song JH, et al. Prevalence and characterization of extended-spectrum beta-lactamase-producing Enterobacteriaceae isolated in Korean hospitals. Diag Microbiol Infect Dis 2008;61:453-9.

2. Rodriguez-Bano J, Navarro MD, Romero L, et al. Bacteremia due to extended-spectrum beta-lactamase-producing Escherichia coli in the CTX-M era: A new clinical challenge. Clin Infect Dis 2006;43:1407-14.

3. Paterson DL, Bonomo RA. Extended-spectrum beta-lactamases: A clinical update. Clin Microbiol Rev 2005;18:657-86.

4. Canton R, Coque TM. The CTX-M beta-lactamase pandemic. Curr Opin Microbiol 2006;9:466-75.

5. Coque TM, Novais A, Carattoli A, et al. Dissemination of clonally related Escherichia coli strains expressing extended-spectrum betalactamase CTX-M-15. Emerg Infect Dis 2008;14:195-200.
Therapeutic options for ESBL producers are severely limited because they are often MDR. Both ESBL-producing $E$ coli and $K$ pneumoniae displayed high coresistance rates to the fluoroquinolones, trimethoprim/sulfamethoxazole, doxycycline and gentamicin, with a high percentage exhibiting a MDR phenotype. Although resistance rates were high, ESBLproducing $E$ coli and $K$ pneumoniae still remained susceptible to the carbapenems and ESBL-producing E coli remained susceptible to tigecycline. Alternative therapies such as nitrofurantoin (urinary tract infection only) and colistin (polymyxin E) still remain potential options for ESBLproducing $E$ coli because they were $98.0 \%$ and $96.0 \%$ susceptible, respectively.

Molecular typing of the isolates revealed that the majority of ESBL producers were genetically unrelated. This suggests that horizontal transfer of plasmids bearing the ESBL gene plays a larger role in the spread of ESBLs across Canada compared with clonal spread of an epidemic strain.

In summary, we update the prevalence and molecular epidemiology of ESBL-producing Enterobacteriaceae from hospitals across Canada in 2007. The prevalence of ESBL-producing E coli, K pneumoniae, Koxytoca and P mirabilis in Canadian hospitals is 3.4\%, 1.6\%, 0\% and 0\%, respectively. CTX-M has become the most prevalent enzyme among both ESBL-producing E coli and $K$ pneumoniae. Coresistance rates were high among ESBL producers to many non-betalactam agents, with a high percentage exhibiting a MDR phenotype. The spread of ESBL producers across Canada is polyclonal and is not due to the clonal spread of a single strain.

ACKNOWLEDGEMENTS: Patricia Baudry is supported by the Winnipeg Health Sciences Centre Department of Research, the Winnipeg Health Sciences Centre Foundation and the Manitoba Health Research Council. Funding for the CANWARD 2007 study was provided in part by the University of Manitoba, Health Sciences Centre in Winnipeg, National Microbiology LaboratoryHealth Canada, Affinium Inc, Astellas, Bayer, Janssen Ortho Inc, Oryx, Pfizer Canada, TaiGen, Targanta and Wyeth Inc. Special thanks to Nancy Laing, Barb Weshnoweski, Ravi Vashisht, Lisa Bittner and Haley Butcher for technological assistance. The authors wish to thank M Tarka for expert secretarial assistance. The authors also thank the investigators and laboratory site staff at each medical centre that participated in the CANWARD 2007 study. CANWARD data are also displayed at www.can-r.ca, the official Web site of the Canadian Antimicrobial Resistance Alliance (CARA).

6. Clinical and Laboratory Standards Institute. Performance standards for antimicrobial susceptibility testing; 18th Informational Supplement. CLSI document M100-S18. CLSI, Wayne, PA, USA, 2008.

7. Mulvey MR, Bryce E, Boyd D, et al. Ambler class A extended-spectrum beta-lactamase-producing Escherichia coli and Klebsiella spp. in Canadian hospitals. Antimicrob Agents Chemother 2004:48:1204-14

8. Boyd DA, Tyler S, Christianson S, et al. Complete nucleotide sequence of a 92-kilobase plasmid harboring the CTX-M-15 extended-spectrum beta-lactamase involved in an outbreak in long-term-care facilities in Toronto, Canada. Antimicrob Agents Chemother 2004;48:3758-64.

9. Baudry PJ, Nichol K, DeCorby M, et al. Comparison of antimicrobial resistance profiles among extended-spectrum-beta-lactamase-producing 
and acquired AmpC beta-lactamase-producing Escherichia coli isolates from Canadian intensive care units. Antimicrob Agents Chemother 2008;52:1846-9.

10. Pitout JD, Church DL, Gregson DB, et al. Molecular epidemiology of CTX-M-producing Escherichia coli in the Calgary Health Region: The emergence of CTX-M-15-producing isolates. Antimicrob Agents Chemother 2007;51:1281-86.

11. Melano RG, Davidson RJ, Musgrave HL, Forward KR. Cephalosporin resistance in Klebsiella pneumoniae from Nova Scotia, Canada. Diag Microbiol Infect Dis 2006;56:197-205.

12. Zhanel GG, DeCorby M, Laing N, et al. Antimicrobial-resistant pathogens in intensive care units in Canada: Results of the Canadian National Intensive Care Unit (CAN-ICU) study, 2005-2006. Antimicrob Agents Chemother 2008;52:1430-7.

13. Pitout JD, Nordmann P, Laupland KB, Poirel L. Emergence of Enterobacteriaceae producing extended-spectrum beta-lactamases (ESBLs) in the community. J Antimicrob Chemother 2005;56:52-9.

14. Doi Y, Adams-Haduch JM, Paterson DL. Escherichia coli isolate coproducing 16S rRNA methylase and CTX-M-type extendedspectrum beta-lactamase isolated from an outpatient in the United States. Antimicrob Agents Chemother 2008;52:1204-5. 


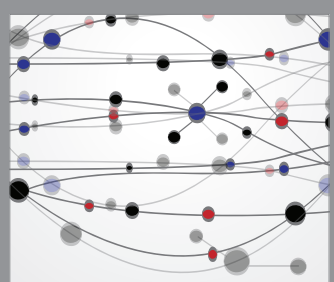

The Scientific World Journal
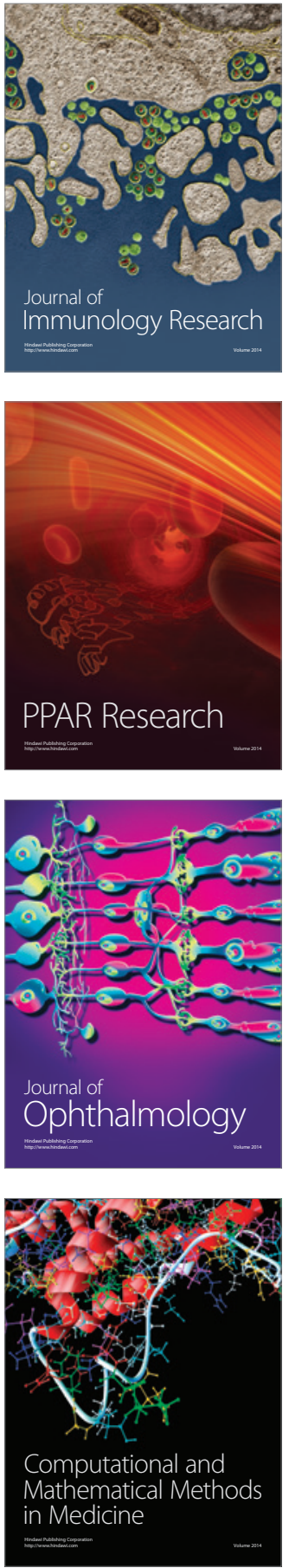

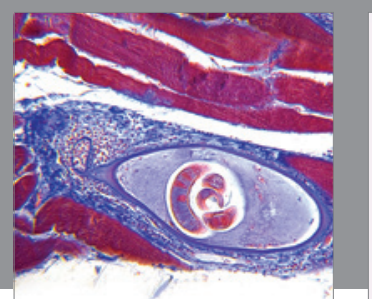

Gastroenterology Research and Practice

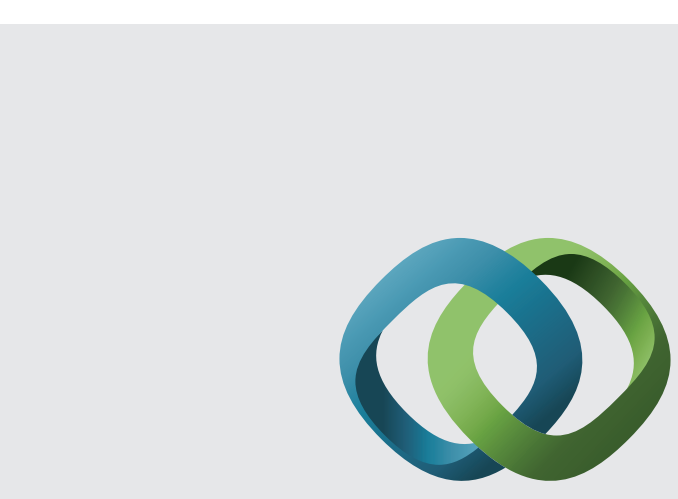

\section{Hindawi}

Submit your manuscripts at

http://www.hindawi.com
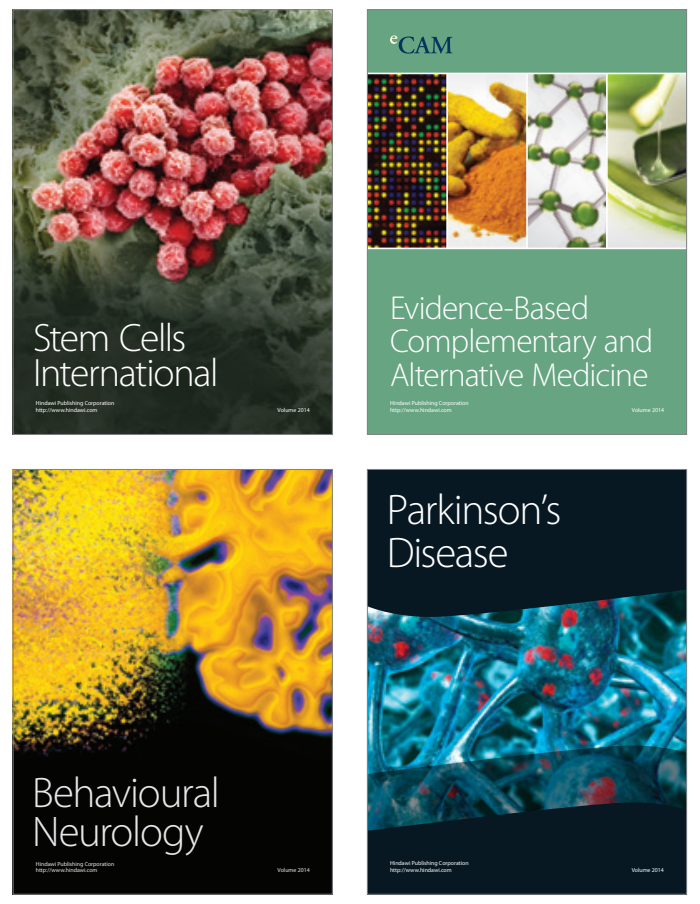
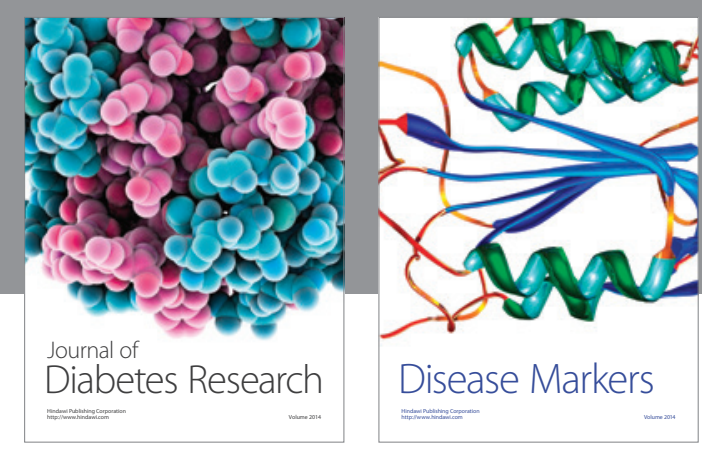

Disease Markers
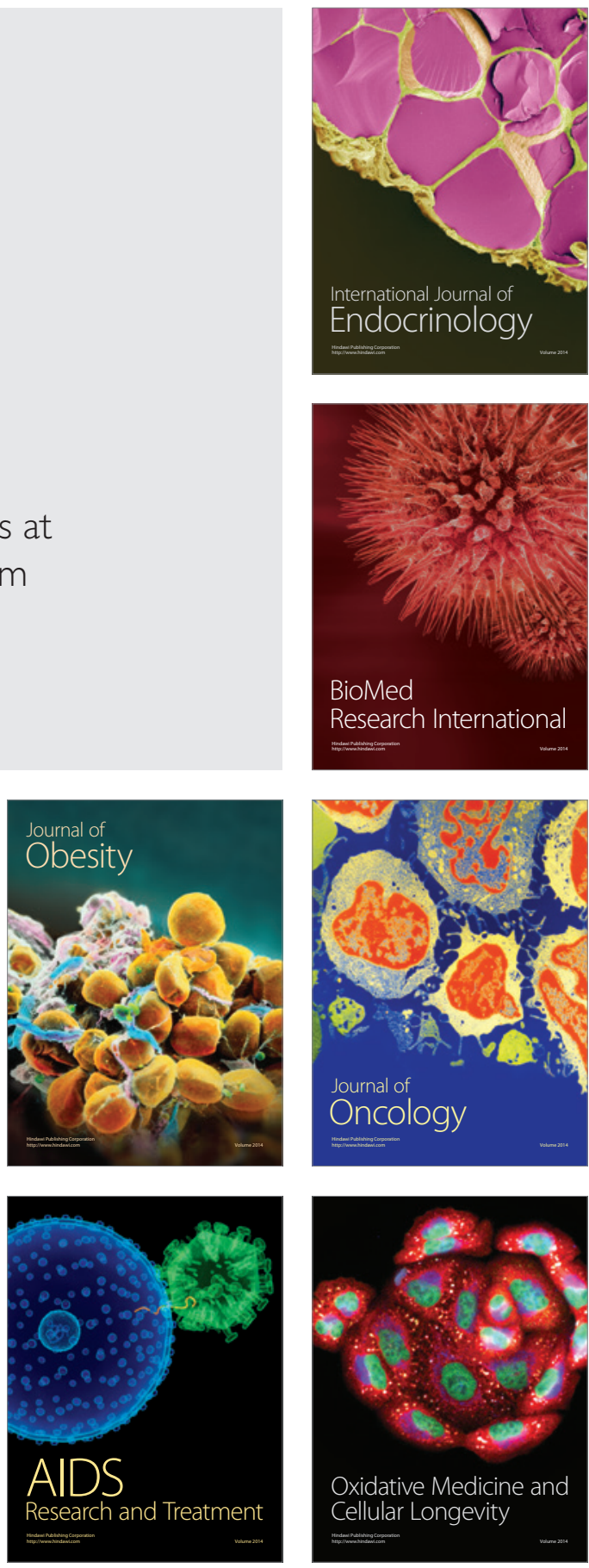